This item was submitted to Loughborough's Research Repository by the author.

Items in Figshare are protected by copyright, with all rights reserved, unless otherwise indicated.

\title{
Enzymatic fluorination of biotin and tetrazine conjugates for pretargeting approaches to positron emission tomography imaging
}

\section{PLEASE CITE THE PUBLISHED VERSION}

https://doi.org/10.1002/cbic.201800234

\section{PUBLISHER}

(c) Wiley

VERSION

AM (Accepted Manuscript)

\section{PUBLISHER STATEMENT}

This work is made available according to the conditions of the Creative Commons Attribution-NonCommercialNoDerivatives 4.0 International (CC BY-NC-ND 4.0) licence. Full details of this licence are available at: https://creativecommons.org/licenses/by-nc-nd/4.0/

\section{LICENCE}

CC BY-NC-ND 4.0

\section{REPOSITORY RECORD}

Lowe, Phillip T., Sergio Dall'Angelo, Andrew Devine, Matteo Zanda, and David O'Hagan. 2019. "Enzymatic Fluorination of Biotin and Tetrazine Conjugates for Pretargeting Approaches to Positron Emission Tomography Imaging". figshare. https://hdl.handle.net/2134/36580. 


\title{
Enzymatic fluorination of biotin and tetrazine conjugates for pre-targeting approaches to PET imaging.
}

\author{
Phillip T. Lowe ${ }^{\dagger},{ }^{a}$ Sergio Dall'Angelo ${ }^{\dagger},{ }^{b}$ Andrew Devine, ${ }^{a}$ Matteo Zanda, ${ }^{b}$ and David O'Hagan*a \\ [a] Dr. P. T. Lowe, A. Devine, Prof. D. O’Hagan \\ School of Chemistry and Centre for Biomolecular Sciences \\ University of St. Andrews, North Haugh, St. Andrews, Fife, KY16 9ST (UK) \\ E-mail: do1@st-andrews.ac.uk
}

[b] Dr. S. Dall'Angelo, Prof. M. Zanda

John Mallard Scottish PET Centre

School of Medicine, Medical Sciences and Nutrition

University of Aberdeen, Foresterhill, Aberdeen, AB25 2ZD (UK)

E-mail: $\underline{\text { m.zanda@abdn.ac.uk }}$

$[\dagger]$ These authors contributed equally to this work.

\begin{abstract}
The use of radiolabelled antibodies and antibody-derived recombinant constructs have shown promise for both imaging and therapeutic use. In this context, the biotin-avidin/streptavidin pairing along with the inverse electron demand Diels-Alder reaction (IEDDA) have found application in pretargeting approaches for positron emission tomography (PET). This study reports the fluorinase enzyme mediated transhalogenation (CIDA substrates to FDA products) of two antibody pre-targeting tools, a FDA-PEG-tetrazine and a [ ${ }^{18}$ F]FDA-PEG-biotin and each is assessed for their compatibility towards IEDDA ligation to trans-cyclooctene or affinity to avidin. A protocol was developed to avoid radiolytically promoted oxidation of biotin during the synthesis of $\left[{ }^{18} \mathrm{~F}\right] \mathrm{FDA}-\mathrm{PEG}$-biotin. The study adds to the repertoire of conjugates for use in fluorinase catalysed radio-synthesis for PET and shows that the fluorinase will accept a wide range of CIDA substrates tethered at C-2 of the adenine ring with a pegylated cargo. The method is exceptional as the nucleophilic reaction with $\left[{ }^{18} \mathrm{~F}\right]$ fluoride takes place in water at neutral $\mathrm{pH}$ and at ambient temperature.
\end{abstract}




\section{Introduction}

Positron emission tomography (PET) has emerged as a valuable tool in clinical imaging due to its high sensitivity and complementarity to other in vivo clinical imaging modalities, such as computerised tomography (CT) and magnetic resonance imaging (MRI). ${ }^{[1]}\left[{ }^{18} \mathrm{~F}\right] \mathrm{Fluoride}$ is the most commonly used radionuclide for PET imaging as it possesses a relatively long half-life $\left(t_{1 / 2}=109.8 \mathrm{~min}\right)$ for a clinical positron emitter and image resolution is enhanced as it has a short positron range ( $2.3 \mathrm{~mm}$ in water).

A recent drive to improve imaging performance by PET has led to a shift from the direct labelling of traditional low molecular-weight and rapidly circulating (hours) radiotracers, which often suffer nonspecific binding and poor localisation in vivo, to the use of large but very high affinity proteins such as monoclonal antibodies or their fragments, which circulate much more slowly (days). ${ }^{[2]}$ Such proteins cannot be usefully labelled by fluorine-18 at point of injection as the isotope half-life is inconsistent with the pre-incubation time required for their location at the target. Instead, a pre-targeted approach is required where the antibody is administered in its unlabelled form, but with a reactive motif attached, and then several hours to days later, a low molecular weight ${ }^{18} \mathrm{~F}$-labelled reactive partner is administered which circulates rapidly and covalently modifies the in situ antibody. Such strategies have begun to exploit bioorthogonal click reactions ${ }^{[3]}$ and make use, for example, of strain promoted alkyne-azide cycloaddition (SPAAC) or inverse electron demand Diels-Alder reactions (IEDDAs), without the need for catalysis. ${ }^{[4]}$ IEDDA based methods in particular involve complimentary tetrazine and trans-cyclooctene (TCO) motifs which combine remarkably rapidly (reaction rates up to $k_{2} 2000$ $\mathrm{M}^{-1} \mathrm{~s}^{-1}$ in 9:1 methanol/water), ${ }^{\left[{ }^{[d]}\right]}$ allowing for protein modification at low radiotracer concentrations.

\section{Radiolabelled effector molecule}

A.<smiles>O=C1[CH]C=C[C@H](c2nncnn2)C=C1</smiles>

B.<smiles>O=C1N[C@H]2[C@H](CS[C@@H]2C2CC2)N1</smiles>

$\|$

\section{Functionalised target- specific component}

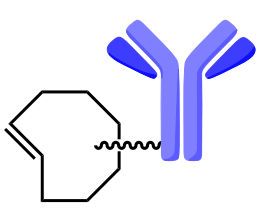

Labelled product
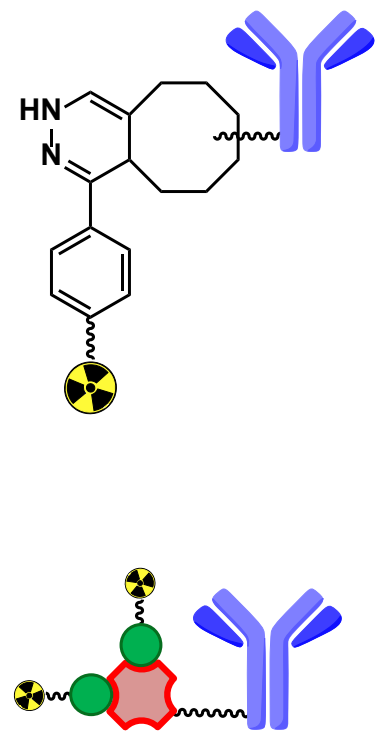

Scheme 1. Schematic diagrams of pre-targeting approaches to PET. A) The inverse electron demand Diels-Alder (IEDDA) bioorthogonal click reaction. B) The (+)-biotin/(strep)avidin affinity pairing.

In this context, the intitial approach has been to fluorinate the TCO motif as direct nucleophilic fluorination of the reactive tetrazine motif is challenging due to decomposition. ${ }^{[5]}$ Thus efficient 
methods for radiolabelling tetrazines with fluorine-18 are desirable. ${ }^{[6]}$ In this regard an Al[ $\left.{ }^{18} \mathrm{~F}\right]$ NOTAlabelled tetrazine tracer was successfully utilised in a pre-targeting PET study, expressing BxPC3 pancreatic cancer xenografts in mice. ${ }^{[4 c]}$ There remains room to explore other ${ }^{18} \mathrm{~F}$-labelled tetrazine strategies and in this study we have investigated enzymatic fluorination in water/buffer under ambient conditions.

Similarly, pre-targeting strategies have been designed around the (+)-biotin/(strep)avidin affinity pairing. ${ }^{[7]}$ The interaction is among the strongest non-covalent interactions $\left(K_{d}=1 \times 10^{-15} \mathrm{M}\right)$ known and is unaffected by extremes of $\mathrm{pH}$ and temperature. Initial approaches to multistep imaging involved the use of unlabelled antibodies conjugated to (+)-biotin, followed by the administration of radiolabelled (strept)avidin. ${ }^{[8]}$ Alternatively, a more efficient pre-targeting approach involves the administration of large (strept)avidin-antibody conjugates, followed by a rapidly circulating, low molecular weight $\left[{ }^{18} \mathrm{~F}\right]$ biotin derivative. ${ }^{[9]}$ There has been concern when employing this strategy regarding the role of endogenous biotin competing with the radiolabelled chaser in vivo, though this has been successfully addressed in mice models through a biotin-deficient diet. ${ }^{[10]}$

Radiolabelling of (+)-biotin has generally been achieved through the pre-synthesis and then coupling of ${ }^{18} \mathrm{~F}$-labelled prosthetic groups, typically $\left[{ }^{18} \mathrm{~F}\right] 4$-fluorobenzylamine ${ }^{[7 b]}, \mathrm{p}-\left[{ }^{18} \mathrm{~F}\right]$ fluorobenzoic acid ${ }^{[10 \mathrm{~b}]}$ and $\left[{ }^{18} \mathrm{~F}\right] F D G{ }^{[11]}$. The approach involves several steps and requires efficient fluorination strategies. Direct labelling approaches, such as the nucleophilic fluorination of a (+)-biotin-mesylate precursor are more appealing. ${ }^{[12]}$ We have been exploring an even more direct approach involving enzymatic fluorination, which can be accomplished without drying the $\left[{ }^{18} \mathrm{~F}\right]$ fluoride which is generated in a cyclotron in $\left[{ }^{18} \mathrm{O}\right]$ water, prior to nucleophilic chemistry. Such an approach requires minimal manipulation of the radioisotope. A similarly direct approach has been explored with boroaryl functionalized (+)-biotin, ${ }^{[13]}$ however in order to avoid deboronylation during the radiolabelling 
protocol

a low<smiles>CSCC[C@H](O)C(=O)O[Na]</smiles>

B.

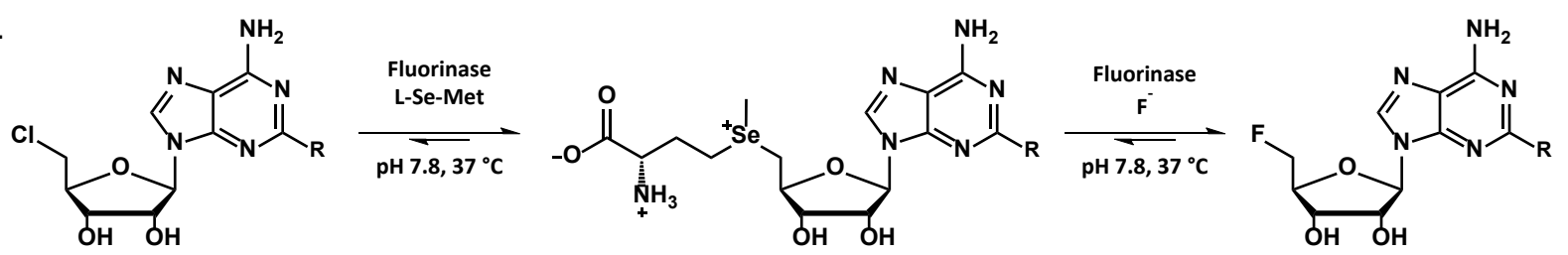
$R=$ s. $^{\text {C CIDA }} 4$

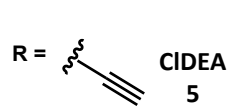

$R=s^{2}$<smiles>[AsH2]</smiles><smiles>CC#CCOC(C)CCOCC</smiles>
Alkyne/azide
"click" "click"<smiles>CCCC[C@H]1NC(=O)[C@H](CC)NC(=O)[C@H](CC(=O)O)NC(=O)CCCCNC1=O</smiles>

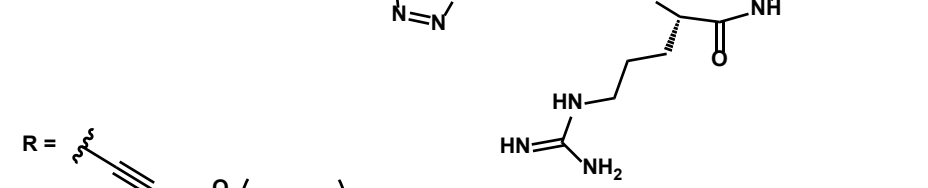

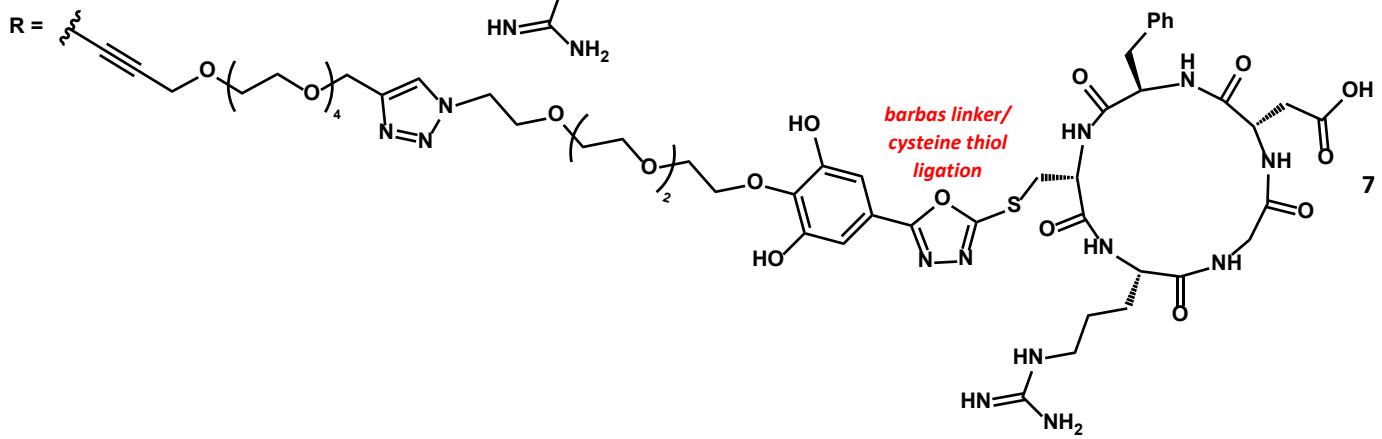

Scheme 2. A) The native reaction catalyzed by the fluorinase enzyme. B) Fluorinase mediated transhalogenation reaction of C-2 modified substrates, 6 and $\mathbf{7}$ exemplify previously achieved alkyne/azide "click"[14] and barbas linker/thiol-ligation ${ }^{[15]}$ bioconjugation strategies.

The fluorinase enzyme catalyses the conversion of S-adenosyl-L-methionine (AdoMet) and fluoride ion to generate 5'-fluoro-5'-deoxyadenosine (5'-FDA, Scheme 2). ${ }^{[16]}$ It also catalyses the nucleophilic displacement of chloride by L-methonine in the reverse direction to generate AdoMet, ${ }^{[17]}$ and if fluoride is present in this reaction 5'-FDA is formed in a sequential step, such that an overall transhalogenation reaction occurs. Moreover, the replacement of AdoMet with AdoSeMet increases the overall transhalogenation efficiency, as selenium is a better nucleophile and leaving group than sulfur (Scheme 2). The fluorinase displays a high degree of substrate specificity, however it can tolerate an acetylene moiety at the $\mathrm{C} 2$ position on the adenine base of 5'-CIDA, additionally a pegylated cargo can also be tethered to the terminus of this acetylene. In this way the fluorinase will catalyse 'last-step' aqueous $\left[{ }^{18}\right.$ F]fluorination of 5'-CIDA-PEG-peptides. ${ }^{[14]}$ To date, methodologies to 
permit bioconjugation of RGD peptides to the fluorinase binding 5'-CIDA moiety either through 'click' based chemistry (via azide functionalized peptides) ${ }^{[14,18]}$ or utilising a modified Barbas bioconjugation strategy (via cysteine containing peptides) ${ }^{[15]}$ have been developed (Scheme 2). Recently, the fluorinase enzyme has also become the target of engineering via directed evolution, in an effort to achieve higher radiochemical conversions (RCC) and broaden the structural diversity of substrates. ${ }^{[19]}$
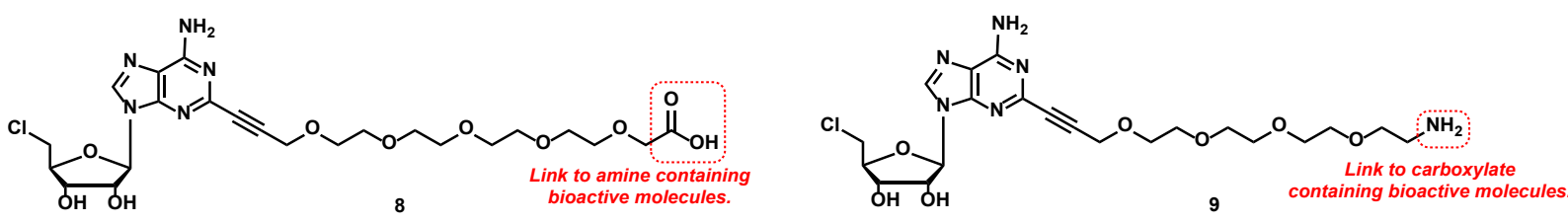

Scheme 3. Design of fluorinase binding CIDA-PEG-acid 8 and CIDA-PEG-amine 9 constructs for amide bond ligation to biologically relevant molecules.

In order to demonstrate a wider array of conjugation methods (employing amide linkage via CIDAPEG-acid 8 and CIDA-PEG-amine 9, Scheme 3) compatible with fluorinase labelling of higher molecularweight proteins, we now report the fluorinase mediated transhalogenation of CIDA-PEG-tetrazine 16 to FDA-PEG-tetrazine $\mathbf{1 7}$ demonstrating compatibility with the tetrazine ring under ambient, aqueous conditions. Similarly CIDA-PEG-biotin $\mathbf{2 6}$ was used in a proof of principle study to deliver a biotin radiotracer, $\left[{ }^{18} \mathrm{~F}\right] \mathbf{2 7}$, as a tool for radiolabelling pre-targeted (strept)avidin conjugated antibodies.

\section{Results and Discussion}

\section{Synthesis of CIDA-PEG-acid 8 and CIDA-PEG-tetrazine 16}

A three step approach was employed for the synthesis of both CIDA-PEG-tetrazine 16 and CIDA-PEGbiotin 26. ${ }^{[14,18 b]}$ This involved the synthesis of a fluorinase compatible 5 '-chloro-5'-deoxyadenosine attached to an amine (9) or carboxylic acid (8) functionality through a PEG spacer. Amide coupling to either benzylamino tetrazine $\mathbf{1 5}$ or the carboxylate of (+)-biotin 25, generated tetrazine $\mathbf{1 6}$ (Scheme 4) or CIDA-PEG-biotin $\mathbf{2 6}$ (Scheme 5) constructs respectively. Briefly, 5'-chlorodeoxy-2-iodo-adenosine 13, a key intermediate in these syntheses, was prepared from guanosine using a previously established protocol. ${ }^{[18 b]}$ The synthesis of $\mathbf{1 6}$ required that the pegylated linker was functionalized with an alkyne terminus. This was accomplished by first treating tetraethylene glycol $\mathbf{1 0}$ with propargyl bromide to provide the monoalkylated PEG derivative 11, which, after purification, was treated with tert-butyl bromoacetate to afford 12. This PEG linker serves two purposes; firstly, it aids in the aqueous solubility of the conjugate, an essential requirement for fluorinase catalysis. Secondly, the linker serves to project any functionalized moiety from the surface of the fluorinase and into the bulk solvent. 


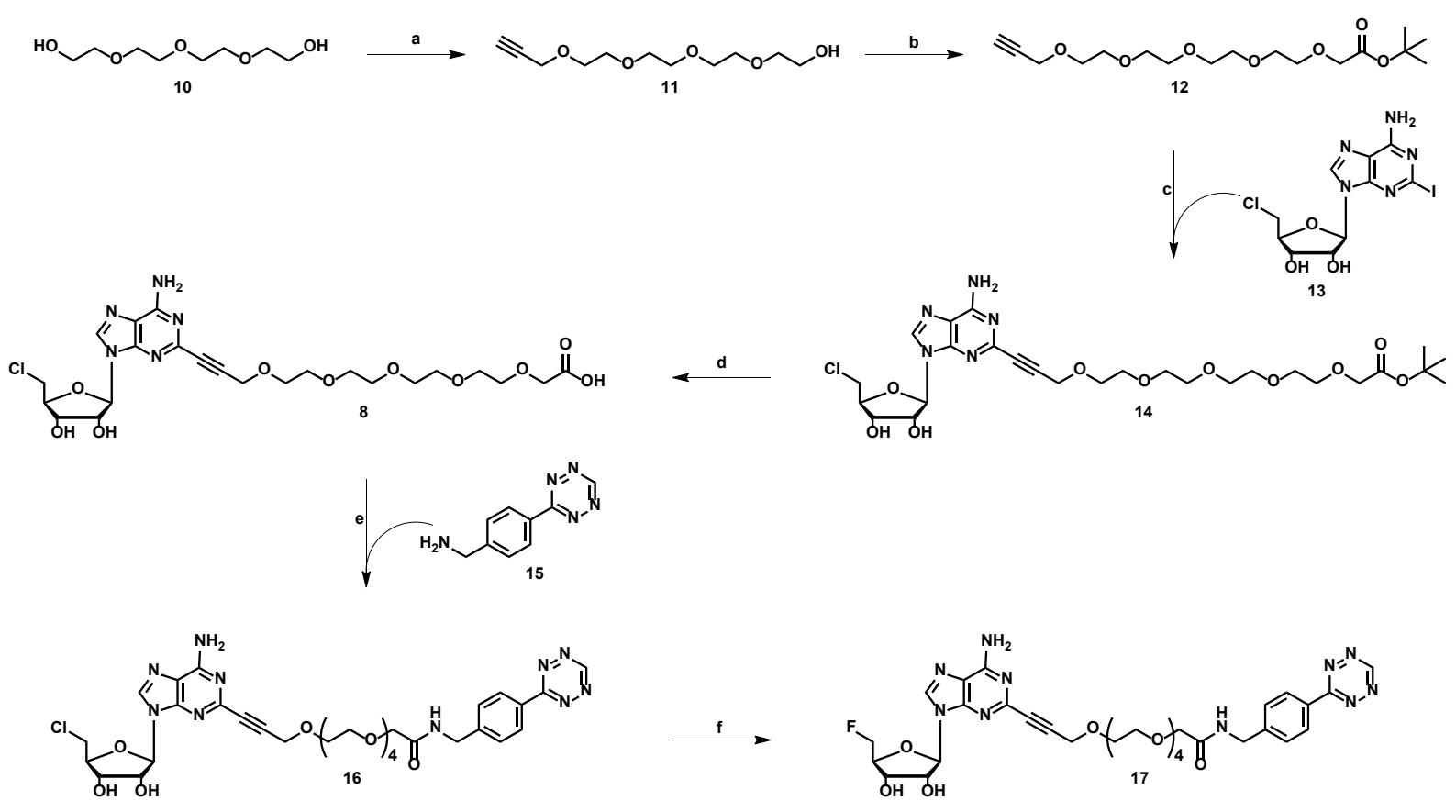

Scheme 4. Synthesis of CIDA-PEG-acid 8, CIDA-PEG-tetrazine 16 and FDA-PEG-tetrazine 17. Reagents and conditions: a) $\mathrm{NaH}$, propargyl bromide, THF, $0{ }^{\circ} \mathrm{C}$ to r.t., overnight; b) $\mathrm{NaH}$, tert-butyl bromoacetate, $\mathrm{THF}, 0{ }^{\circ} \mathrm{C}$ to r.t., overnight; c) $\mathrm{Pd}_{2}\left(\mathrm{dba}_{3}, \mathrm{Et}_{3} \mathrm{~N}, \mathrm{Cul}, \mathrm{DMF}, 80^{\circ} \mathrm{C}, 24 \mathrm{~h}\right.$; d) TFA, DCM, $0{ }^{\circ} \mathrm{C}$ to r.t., $45 \mathrm{~min}$; e) PyBOP, DIPEA, DMF, r.t., 24 h; f) Fluorinase, L-Se-Met, KF, phosphate buffer (pH 7.8), $37^{\circ} \mathrm{C}, 72 \mathrm{~h}$.

With both 12 and 13 in hand, our attention turned to further assembly via Sonogashira cross-coupling. This was accomplished, ${ }^{[20]}$ using an excess of alkyne 12 over 5'-chlorodeoxy-2-iodo-adenosine $\mathbf{1 3}$ in the $\mathrm{Pd}_{2}(\mathrm{dba})_{3}$ catalysed reaction. The CIDA-PEG-ester 14 was recovered in high purity after chromatography and C18 cartridge purification. CIDA-PEG-ester 14 was treated with TFA to generate 8 as a TFA salt, and this could be used directly in the subsequent coupling reactions, without the need for further purification. Finally, an amide coupling reaction (PyBOP, DIPEA) was employed to attach carboxylic acid 8 to benzylamino tetrazine 15 (Scheme 4). This afforded the CIDA-PEG-tetrazine 16 conjugate in high purity after preparative HPLC.

\section{Evaluation of CIDA-PEG-tetrazine as a substrate for fluorinase mediated transhalogenation}

Substrate 16 was incubated with the fluorinase $\left(1 \mathrm{mg} \mathrm{mL}^{-1}\right.$, these relatively high amounts are due to the fluorinase having a slow kcat of $\left.0.03 \mathrm{~min}^{-1}\right)^{[17]}$ under previously established conditions in phosphate buffer at pH 7.8 (see Supporting Information). A time course profile (Figure 1) showed that 16 was an excellent substrate for enzyme catalysed transhalogenation generating FDA-PEG-tetrazine 17 , in $\sim 60 \%$ conversion after $4 \mathrm{~h}$, and this offers a new approach to fluorinating tetrazine derivatives. Importantly, no obvious degradation was observed within the initial hours of these experiments (the timeframe required for radiolabeling experiments), indicating that CIDA-PEG-tetrazine and its fluorinated analogue are stable under these conditions. The additional peak observed at $12.5 \mathrm{~min}$ is indicative of the intermediate L-Se-Met adduct (which consistently possesses a greater retention time to that of its corresponding CIDA and FDA derivatives). 


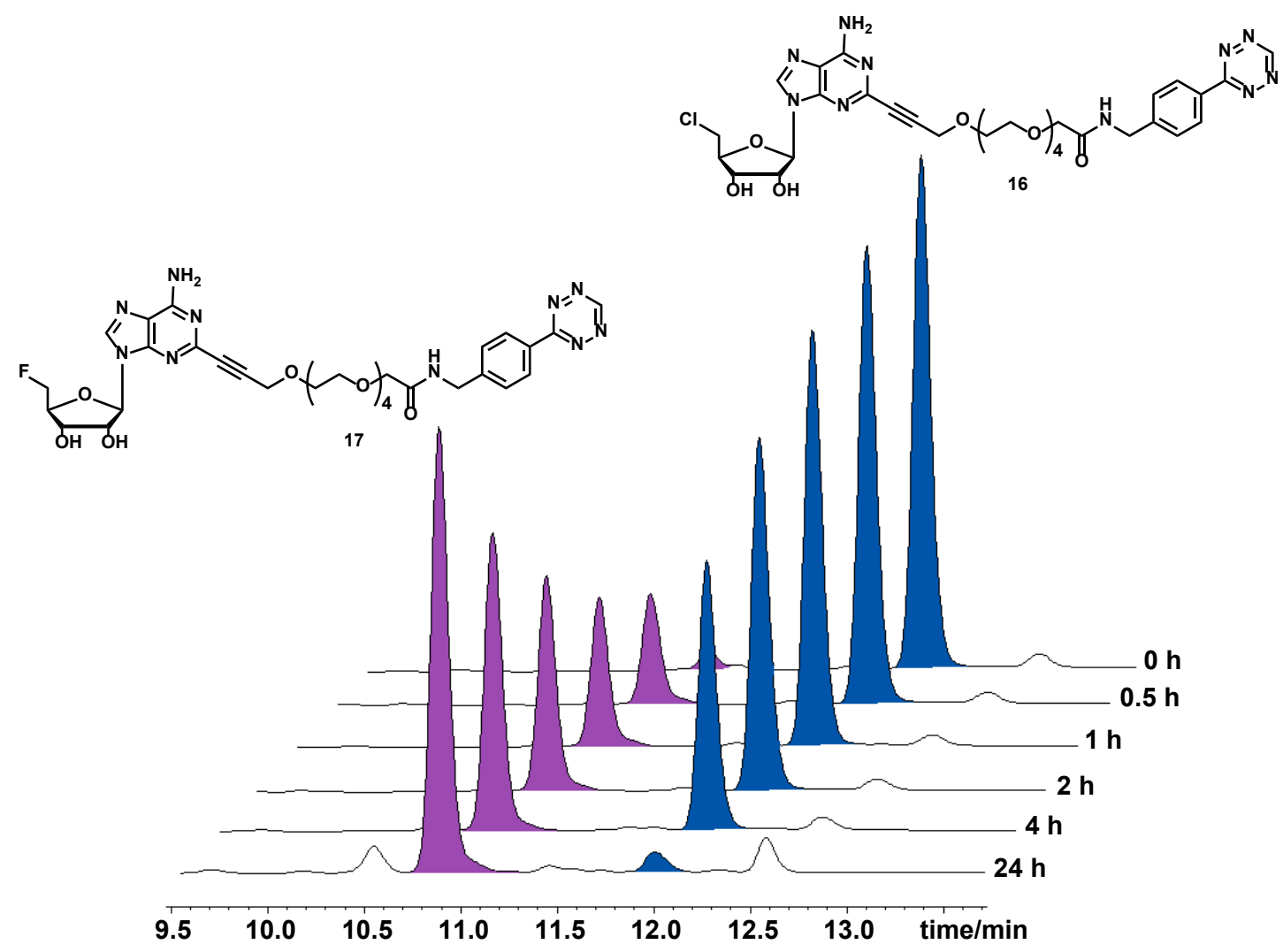

Figure 1. HPLC time course (UV, $254 \mathrm{~nm}$ ) of the incubation of CIDA-PEG-tetrazine 16, blue ( $\left.t_{\mathrm{R}}=11.9 \mathrm{~min}\right)$, with the fluorinase, L-Se-Met, KF, phosphate buffer (pH 7.8) at $37^{\circ} \mathrm{C}$. Traces show the formation of FDA-PEG-tetrazine 17, purple $\left(t_{R}=10.8 \mathrm{~min}\right)$, and the consumption of CIDA-PEG-tetrazine 16. For full conditions see the Experimental Section and Supporting Information.

\section{CIDA-PEG-tetrazine/dienophile IEDDA ligation}

With FDA-PEG-tetrazine $\mathbf{1 7}$ in hand, it was explored for its ability to participate in IEDDA-initiated ligation. For this study $(E)$-cyclooct-4-enol $\mathbf{1 8}$ was chosen as a coupling partner. Thus, a solution (40 $\mu \mathrm{l}, 50 \mathrm{mM}$ ) of (E)-cyclooct-4-enol in DMSO was added to an aqueous solution of $\mathbf{1 7}$, and the mixture was incubated at room temperature for $2 \mathrm{~min}$. An aliquot was then subjected to HPLC and HRMS analysis of the new product isolated was consistent with the formation of the fully aromatised ligated product 19 (Scheme 5).

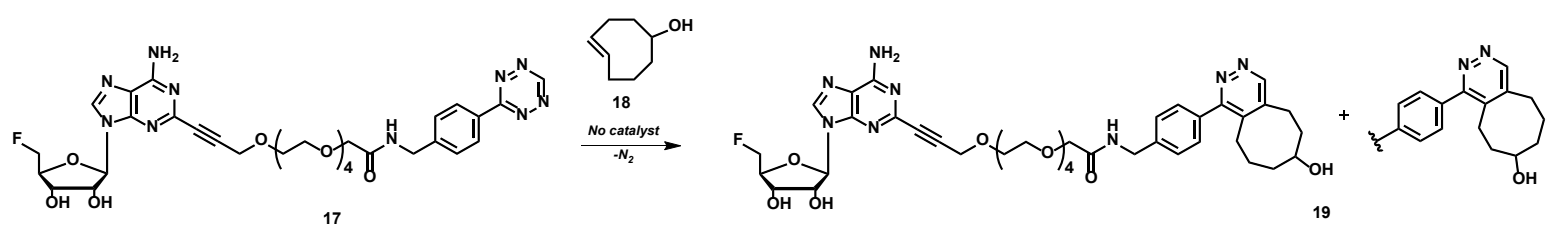

Scheme 5. IEDDA initiated conjugation between 17 and (E)-cyclooct-4-enol 18 (identity of fully aromatised ligation product 19 was confirmed by HRMS after isolation by HPLC. 


\section{Last step enzymatic ${ }^{18} \mathrm{~F}$ labelling of 16 to $\left[{ }^{18} \mathrm{~F}\right] \mathrm{FDA}-\mathrm{PEG}$-tetrazine}

An enzymatic transhalogenation in the presence of $\left[{ }^{18} \mathrm{~F}\right]$ fluoride was investigated with $\mathbf{1 6}$ and its conversion into $\left[{ }^{18} \mathrm{~F}\right] \mathrm{FDA}-\mathrm{PEG}$-tetrazine $\left(\left[{ }^{18} \mathrm{~F}\right] 17\right)$ was clearly demonstrated against a product reference. Using the previously established protocol, ${ }^{[15]}\left[{ }^{18} \mathrm{~F}\right] \mathbf{1 7}$ was generated with an approximate $10 \%$ radiochemical conversion (decay uncorrected) after a $30 \mathrm{~min}$ incubation with the fluorinase (Figure S46). Isolation of $\left[{ }^{18} \mathrm{~F}\right] 17$ by semi-prep HPLC afforded the radiolabelled product with two minor radiolabelled impurities (Figure S47). This process requires optimisation for pre-clinical dosing, however it is clear that the tetrazine moiety is compatible with the fluorinase radiolabelling protocol.

\section{Synthesis of CIDA-PEG-amine 9 and CIDA-PEG-biotin 26}

The synthesis of CIDA-PEG-biotin $\mathbf{2 6}$ followed a similar strategy to that used for CIDA-PEG-tetrazine 16. Firstly, a pegylated linker was required with alkyne and amine termini. For this alcohol $\mathbf{1 1}$ was treated with tosyl chloride and then $\mathbf{2 0}$ was subjected to nucleophilic displacement with sodium azide to generate azide 21. A Staudinger reduction of this azide afforded free amine 22, which was then Boc protected to generate 23 .

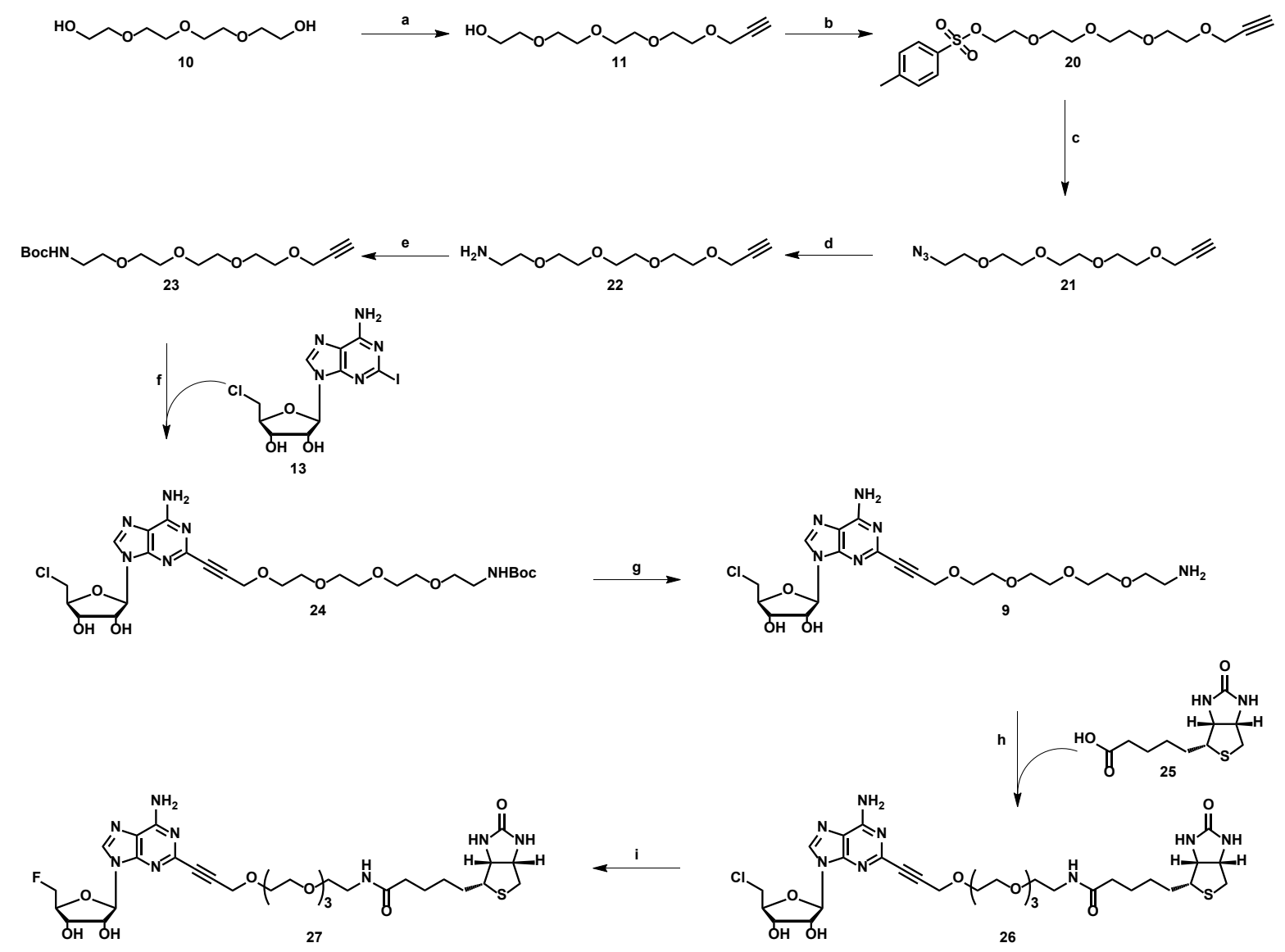

Scheme 6. Synthesis of CIDA-PEG-amine 9, CIDA-PEG-biotin 26 and FDA-PEG-biotin 27. Reagents and conditions: a) $\mathrm{NaH}$, propargyl bromide, THF, $0{ }^{\circ} \mathrm{C}$ to r.t., overnight; b) Tosyl chloride, Et ${ }_{3} \mathrm{~N}$, THF, r.t., 20 h; c) NaN 3 , DMF, 50 ${ }^{\circ} \mathrm{C}, 18 \mathrm{~h}$; d) $\mathrm{PPh}_{3}, \mathrm{H}_{2} \mathrm{O}$, THF, r.t., 48 h; e) (Boc) ${ }_{2} \mathrm{O}, \mathrm{Et}_{3} \mathrm{~N}, \mathrm{MeOH}$; f) $\mathrm{Pd}_{2}(\mathrm{dba})_{3}, \mathrm{Et}_{3} \mathrm{~N}, \mathrm{Cul}, \mathrm{DMF}, 80{ }^{\circ} \mathrm{C}, 24 \mathrm{~h}$; g) TFA, $\mathrm{DCM}, 0{ }^{\circ} \mathrm{C}$ to r.t., $45 \mathrm{~min}$; h) PyBOP, DIPEA, DMF, r.t., 24h; i) Fluorinase, L-Se-Met, KF, phosphate buffer (pH 7.8), $37^{\circ} \mathrm{C}, 48 \mathrm{~h}$. 
A Sonogashira cross-coupling was carried out with an excess of alkyne $\mathbf{2 3}$ over 5'-chlorodeoxy-2-iodoadenosine $\mathbf{1 3}$ using the previously described protocol to generate CIDA-PEG-protected amine 24, after HPLC purification, in high purity. Deprotection of $\mathbf{2 4}$ with TFA led to free amine $\mathbf{9}$ (as a TFA salt) which was used directly in subsequent coupling reactions, without the need for further purification. As with carboxylic acid 8, amine 9 offers a complementary tool for the fluorinase $\left[{ }^{18} \mathrm{~F}\right]$-labelling, for conjugation to the C-termini of bioactive peptides. Amide coupling (PyBOP, DIPEA) allowed preparation of the CIDA-PEG-biotin conjugate $\mathbf{2 6}$ in good yield and high purity after HPLC purification.

\section{Evaluation of CIDA-PEG-biotin as a substrate for fluorinase mediated transhalogenation}

As a prelude to $\left[{ }^{18} \mathrm{~F}\right]$-radiolabelling a 'cold' transhalogenation reaction with CIDA-PEG-biotin $\mathbf{2 6}$ was explored with the fluorinase. Accordingly, substrate $\mathbf{2 6}$ was incubated with the fluorinase $\left(1 \mathrm{mg} \mathrm{mL}^{-1}\right)$ L-Se-Met $(75 \mu \mathrm{M})$ and KF $(50 \mathrm{mM})$ in phosphate buffer, at pH 7.8 (see Supporting Information). An analytical time course profile revealed chloride $\mathbf{2 6}$ to be an excellent substrate for fluorinase mediated transhalogenation generating FDA-PEG-biotin 27, with an almost $80 \%$ conversion after $4 \mathrm{~h}$. No reaction was observed in the absence of the fluorinase and the water solubility of $\mathbf{2 6}$ circumvented any requirement to add DMSO. A significant advantage in such reactions, as adding DMSO can complicate work up by promoting gelling on heat denaturation.

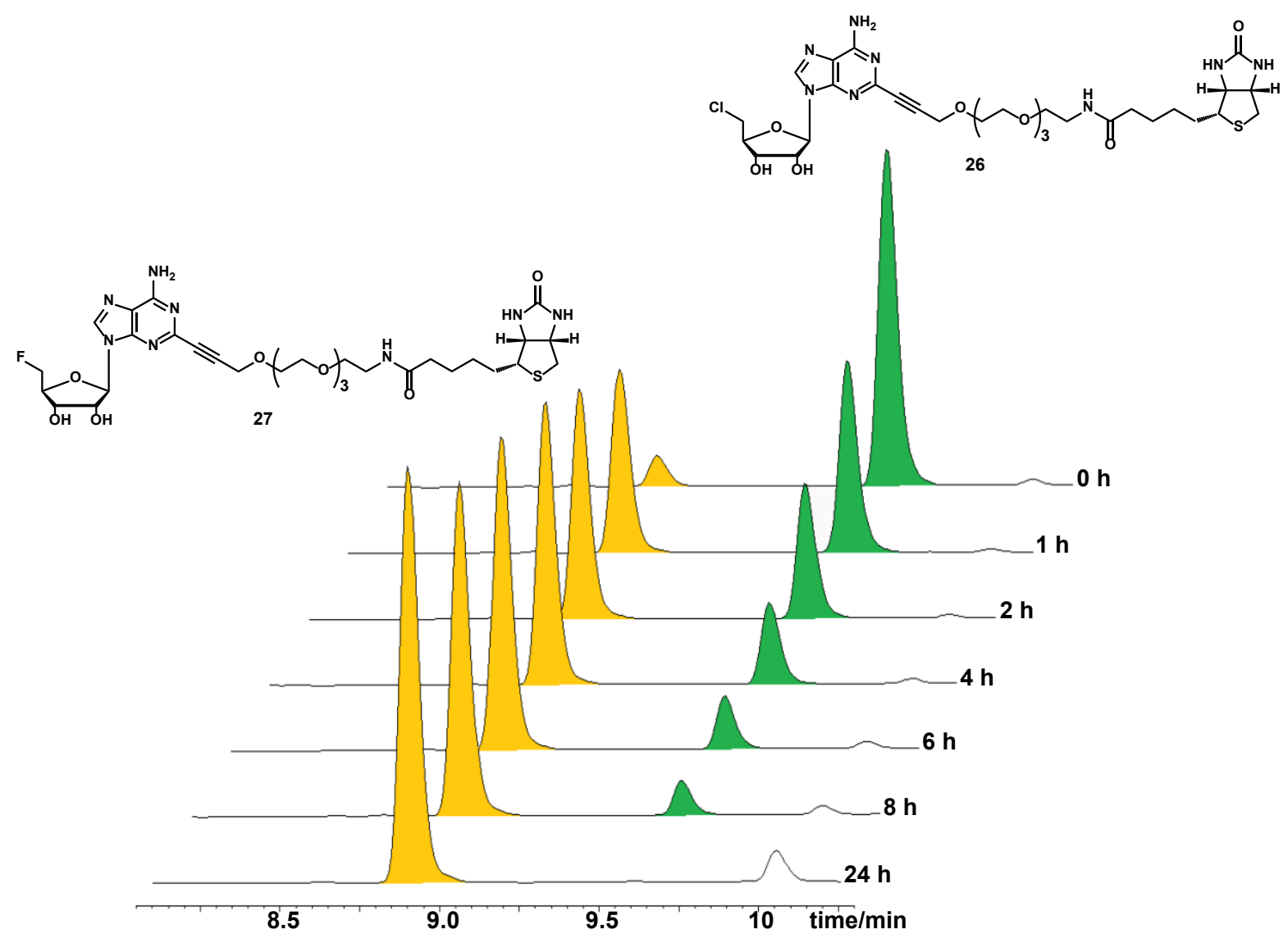

Figure 2. HPLC time course (UV, $254 \mathrm{~nm}$ ) of the incubation of CIDA-PEG-biotin 26, green ( $\left.t_{R}=9.5 \mathrm{~min}\right)$, with the fluorinase, L-Se-Met, KF, phosphate buffer $\left(\mathrm{pH} \mathrm{7.8)}\right.$ at $37^{\circ} \mathrm{C}$. Traces show the formation of FDA-PEG-biotin 27, yellow $\left(t_{R}=8.9 \mathrm{~min}\right.$ ), and the consumption of CIDA-PEG-biotin 26. For full conditions see the Experimental Section and Supporting Information. 
The transhalogenation of $\mathbf{2 6}$ was carried out on a scale sufficient for isolation of an analytical sample of FDA-PEG-biotin $\mathbf{2 7}$ to confirm its identity by NMR. A suitable sample was also required to evaluate its binding affinity to avidin (see Supporting Information). The reaction was again monitored by HPLC and was terminated by heat precipitation and centrifugation to remove the enzyme. Purification was accomplished via semi-prep HPLC to obtain 27 (3mg) in high purity.

\section{FDA-PEG-biotin/avidin Binding Assay}

The avidin binding affinity of the newly synthesised FDA-PEG-biotin 27 was determined using a colorimetric HABA assay. The assay exploits the UV spectral changes that occur upon the binding of 4'-hydroxyazobenzene-2-carboxylic acid (HABA) to avidin. The HABA/avidin interaction is a relatively weak one $\left(K_{d}=5.8 \times 10^{-6} \mathrm{M}\right.$ versus that of $(+)$-biotin/Avidin; $\left.K_{d}=1 \times 10^{-15} \mathrm{M}\right)$, and as such free (+)-biotin, or indeed 27 , will readily displace the HABA dye and result in a decrease in absorbance at $500 \mathrm{~nm}$ wavelength. FDA-PEG-biotin $\mathbf{2 7}$ was found to inhibit the HABA/avidin complex in a dose dependant manner (Figure 3 ) and with a similar affinity to that between avidin and (+)-biotin. The PEG spacer and the FDA moiety of the construct do not impede the binding interaction of $\mathbf{2 7}$ with avidin, thus $\left[{ }^{18} \mathrm{~F}\right] \mathbf{2 7}$ has good potential as a candidate tracer for streptavidin-conjugated antibody PET studies.

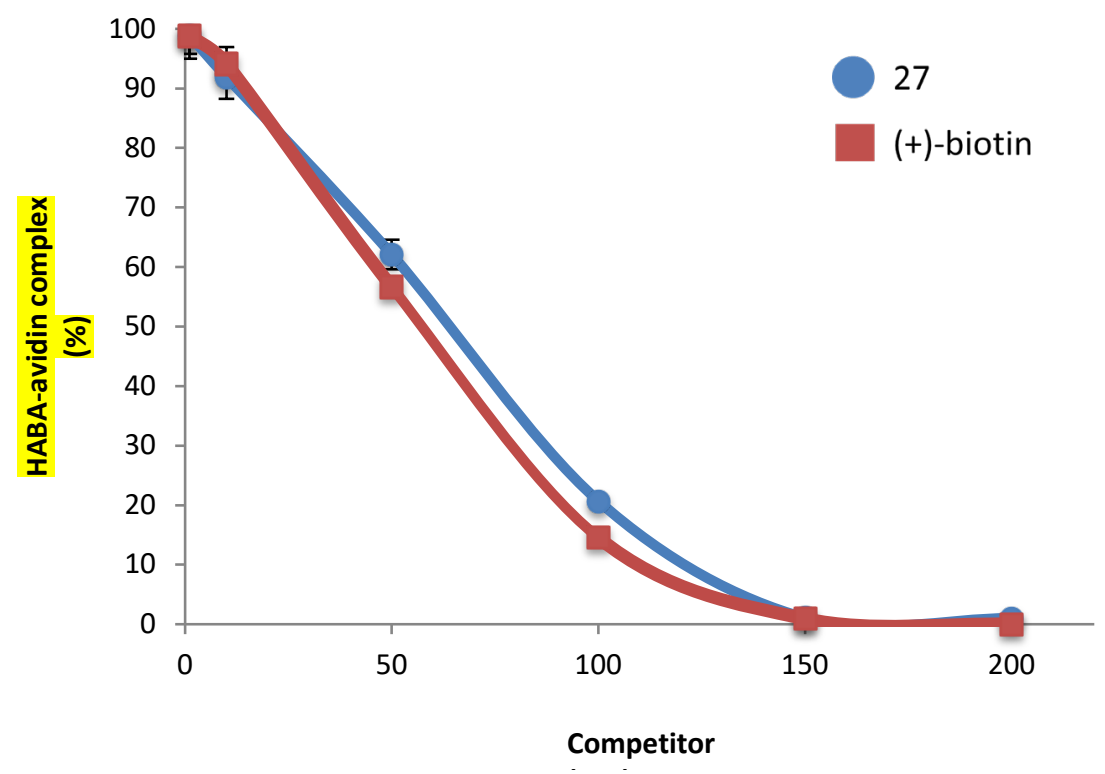

Figure 3. Inhibition of the HABA/avidin complex by (+)-biotin (maroon squares) and FDA-PEG-biotin 27 (blue circles). Data are representative of three different experiments.

\section{Last step enzymatic ${ }^{18} \mathrm{~F}$ labelling of biotin}

An enzymatic transhalogenation was performed with $\mathbf{2 6}$ in the presence of $\left[{ }^{18} \mathrm{~F}\right]$ fluoride, and its conversion into $\left[{ }^{18} \mathrm{~F}\right]$ FDA-PEG-biotin $\left(\left[{ }^{18} \mathrm{~F}\right] 27\right)$ was monitored. For hot labelling an $\left[{ }^{18} \mathrm{O}\right]$ aqueous, 
solution of $\left[{ }^{18} \mathrm{~F}\right]$ fluoride at $\mathrm{GBq}$ levels is generated and then an aliquot (MBq of $\left[{ }^{18} \mathrm{~F}\right]$ fluoride) is added to the biotransformation solution in buffer at pH 7.8 (see Experimental Section). The concentrations are such that these fluorinase-catalyzed radiochemical reactions are no longer catalytic, as the enzyme is in the micromolar range with $\left[{ }^{18} \mathrm{~F}\right]$ fluoride ion in the pico-molar range. In this manner the stoichiometry is dramatically reversed relative to the cold transhalogenation reactions. During these experiments $\left[{ }^{18} \mathrm{~F}\right] 27$ was produced with a $30-40 \%$ radiochemical conversion after only $30 \mathrm{~min}$ incubation with the fluorinase. Figure 4 shows the radiochemical HPLC trace of the supernatant of a reaction mixture at this time point.

A<smiles>CC(C)OCCOCCNC(=O)CCCCC1SC[C@@H]2NC(=O)N[C@H]12</smiles>

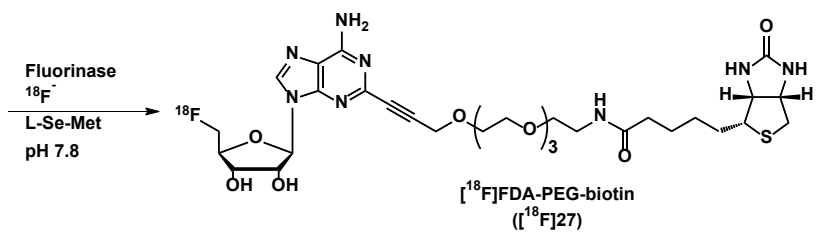

B

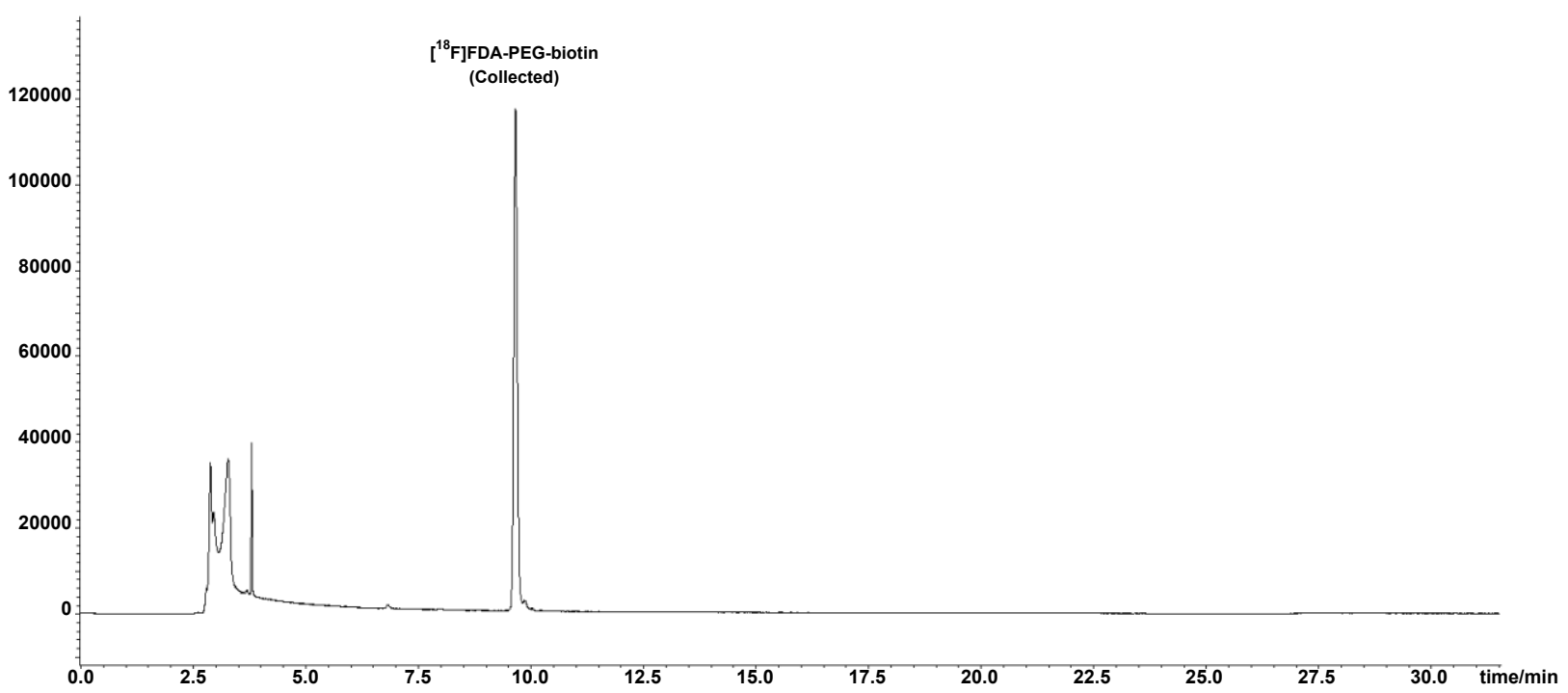

Figure 4. (A) Reaction scheme of the fluorinase catalysed transhalogenation of 26 to $\left.{ }^{18} \mathrm{~F}\right] \mathrm{FDA}-\mathrm{PEG}$-biotin $\left(\left[{ }^{18} \mathrm{~F}\right] 27\right)$. (B) HPLC radioactivity trace of a fluorinase catalysed conversion of CIDA-PEG-biotin 26 to $\left[{ }^{18} \mathrm{~F}\right] \mathbf{2 7}$ in the

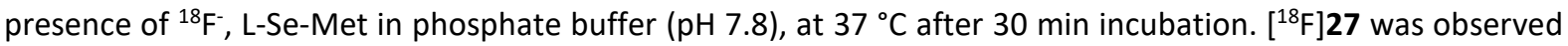
at $t_{R}=9.7 \mathrm{~min}$, showing $40 \%$ radiochemical conversion during this experiment.

After a 30 min incubation, ${ }^{[15]}$ the enzyme was cleanly precipitated by heat denaturation and the solution removed after centrifugation, prior to purification by HPLC. During semi-prep HPLC the eluted peak corresponding to $\left[{ }^{18} \mathrm{~F}\right] 27$ was collected (Figure $4, t_{R}=9.7 \mathrm{~min}$ ), diluted with water $(50 \mathrm{~mL})$ and loaded onto a $\mathrm{C}_{18}$ reverse phase cartridge, which was then washed with water $(20 \mathrm{~mL})$ and $\left[{ }^{18} \mathrm{~F}\right] \mathbf{2 7}$ eluted with ethanol. The purity of $\left[{ }^{18} \mathrm{~F}\right] \mathbf{2 7}$ was determined by analytical radio-HPLC. This revealed the existence of an additional radioactive peak at $t_{R}=4.3 \mathrm{~min}$ (Figure 5). A typical procedure from $\left[{ }^{18} \mathrm{~F}\right]$ fluoride $(457 \mathrm{MBq})$ to the elution of $\left[{ }^{18} \mathrm{~F}\right] 26(59.7 \mathrm{MBq})$ took $1 \mathrm{~h} 19 \mathrm{~min}$. After semi-prep HPLC and C18 cartridge purification, $\left[{ }^{18} \mathrm{~F}\right] \mathbf{2 7}$ was recovered with a radiochemical yield of $13 \%$ (decay uncorrected) and a radiochemical purity of $90 \%$. 


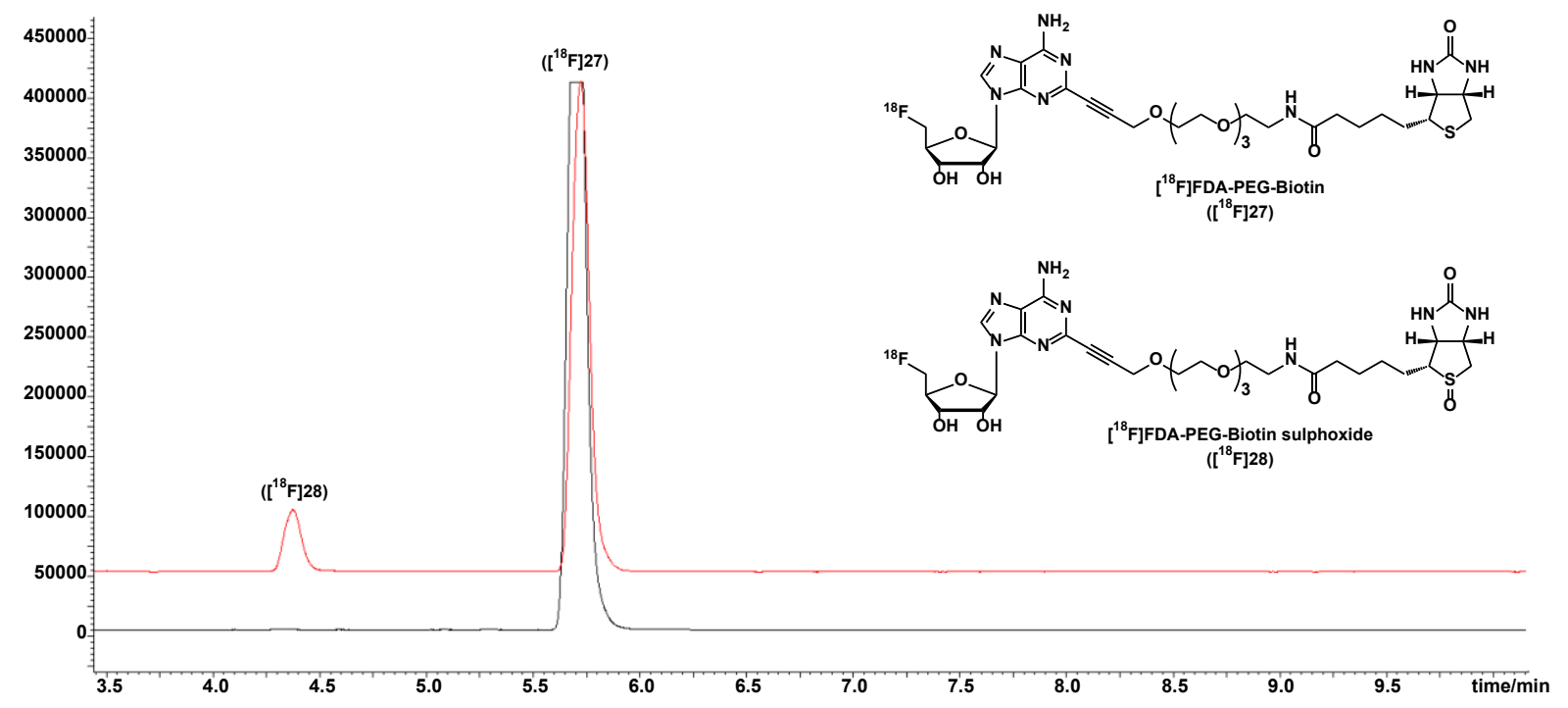

Figure 5. Analytical HPLC radio trace of $\left[{ }^{18} \mathrm{~F}\right] \mathrm{FDA}-\mathrm{PEG}$-biotin $\left(\left[{ }^{18} \mathrm{~F}\right] 27\right)$ acquired using standard purification protocols (red) and optimized purification protocols (black). Structures of $\left[{ }^{18} \mathrm{~F}\right] \mathrm{FDA}-\mathrm{PEG}$-biotin $\left(\left[{ }^{18} \mathrm{~F}\right] 27, \mathrm{t}_{\mathrm{R}}=5.7\right.$ $\mathrm{min})$ and $\left[{ }^{18} \mathrm{~F}\right]$ FDA-PEG-biotin sulfoxide $\left(\left[{ }^{18} \mathrm{~F}\right] 28, \mathrm{t}_{\mathrm{R}}=4.3 \mathrm{~min}\right)$ are shown. For full conditions see the Experimental Section and Supporting Information.

\section{Optimisation of [ $\left.{ }^{18} \mathrm{~F}\right]$ FDA-PEG-biotin purification protocol}

The chemical identity of the impurity $\left(10 \%, t_{R}=4.3 \mathrm{~min}\right.$, Figure 5$)$ in the analytical radio-HPLC trace was elucidated by mass spectrometry analysis. An equivalent peak could be observed in nonradioactive storage of a solution of $\mathbf{2 6}$ in $\mathrm{MeCN} / \mathrm{H}_{2} \mathrm{O}$ at room temperature where the conversion to product 28 is slow ( $3 \%$ at $48 \mathrm{~h}$ ). Isolation by semi-prep HPLC and analysis by LC-MS found a [M+H] mass of $741 \mathrm{amu}$, consistent with FDA-PEG-biotin sulfoxide (28) (see Figure 5). Indeed, previous studies concerning the radiolabelling of biotin observed a similar outcome. ${ }^{[21]}$ Furthermore, biotin sulfoxide is a known product in mammalian catabolism, and is observed in both urine and plasma. ${ }^{[22]}$ The sulfoxide is also known to bind avidin, ${ }^{[23]}$ and thus $\left(\left[{ }^{18} \mathrm{~F}\right] 28\right)$ low levels are unlikely to negatively affect PET studies, however we sought to exclude it from the biotransformation. Studies focused on the radiolytic decomposition of concentrated radiopharmaceuticals ${ }^{[24]}$ indicate that reactive oxygen species (hydroxyl radicals and/or hydrogen peroxide) can be detrimental, and such species could clearly account for the sulfur oxidation of $\left[{ }^{18} \mathrm{~F}\right] \mathbf{2 8}$. In an effort to minimize the formation of $\left[{ }^{18} \mathrm{~F}\right] \mathbf{2 8}$, the fluorinase mediated radiolabelling was repeated however in this instance making use of degassed eluting solvents and established anti-oxidant stabilisers. Approximately the same levels of radioactivity ( $70 \mathrm{MBq}$ ) was collected by semi-prep HPLC into a vial containing $10 \mathrm{mg} / \mathrm{mL}$ ascorbate (a known radical scavenger which is amenable to human use) in water solution ( $45 \mathrm{~mL}$, degassed). This solution was loaded directly onto the $\mathrm{C} 18$ cartridge which had been pre-equilibrated with the same degassed solution and $\left[{ }^{18} \mathrm{~F}\right] \mathbf{2 7}$ was then eluted with ethanol $(0.4 \mathrm{~mL})$. HPLC analysis of the $\left[{ }^{18} \mathrm{~F}\right] 27$ revealed it to be free of $\left[{ }^{18} \mathrm{~F}\right] \mathbf{2 8}$, and with a radiochemical purity of $>99 \%$ (see Figure 5 ). Furthermore, the stability of $\left[{ }^{18} \mathrm{~F}\right] \mathbf{2 7}$ in the ethanol fraction (left open to the atmosphere) was monitored over time by using formulations of both water and aqueous ascorbate $(10 \mathrm{mg} / \mathrm{mL})$ solution. This did not reveal any appreciable oxidation of $\left[{ }^{18} \mathrm{~F}\right] 27$. Under these optimised conditions there was no observable degradation of either $\left[{ }^{18} \mathrm{~F}\right] \mathbf{2 7}$ or its chlorinated precursor. Such stability affords the prospect of the 
development of an automated recycling protocol, potentially incorporating immobilised enzyme (to circumvent the need for centrifugation), to be used in the synthesis of $\left[{ }^{18} \mathrm{~F}\right] \mathbf{2 7}$ to allow for the formulation of higher doses. This fluorinase mediated ${ }^{18} \mathrm{~F}$-labelling methodology provides a novel route into $\left[{ }^{18} \mathrm{~F}\right]$ biotin in the form of $\left[{ }^{18} \mathrm{~F}\right] 27$, and demonstrates a direct 'last step' labelling approach through the formation of a chemically stable $\mathrm{C}^{-18} \mathrm{~F}$ bond from a chlorinated precursor. Furthermore, after optimization of the purification protocol with the use of non-toxic radical scavengers, a radiochemically pure sample of $\left[{ }^{18} \mathrm{~F}\right] \mathbf{2 7}$ was achieved.

\section{$\left[{ }^{18} \mathrm{~F}\right]$ FDA-PEG-biotin streptavidin binding experiments}

To confirm the utility of $\left[{ }^{18} \mathrm{~F}\right] 27$ as a candidate PET tracer for clinical use an assessment of its the streptavidin binding affinity was performed. Accordingly $\left[{ }^{18} \mathrm{~F}\right] 27$ was incubated in PBS buffer (pH 7.8) in the presence and absence of streptavidin (see Supporting Information). Thin layer chromatography was then conducted on both samples (+/- streptavidin) which were analysed using a radio-TLC scanner to determine the percentage of streptavidin bound $\left[{ }^{18} \mathrm{~F}\right] \mathbf{2 7}$. The radio-traces obtained from samples $\left[{ }^{18} \mathrm{~F}\right] 27$ incubated without streptavidin revealed a broad peak with a $\mathrm{R} / \mathrm{F}$ value of 0.39 . Upon incubation with streptavidin $\left[{ }^{18} \mathrm{~F}\right] \mathbf{2 7}$ is almost completely retained (above $96 \%$ ) at the origin of the TLC plate (R/F value of 0.02 , see Supporting Information) indicating its almost complete complexation with streptavidin. This finding is in accordance with the high affinity binding of non radioactive FDA-PEGBiotin 27 and avidin.

\section{Conclusions}

A FDA-PEG-tetrazine construct $\mathbf{1 7}$ and a radiolabelled labelled (+)-biotin derivative $\left[{ }^{18} \mathrm{~F}\right] \mathbf{2 7}$ were generated from their CIDA-chlorinated precursors $\mathbf{1 6}$ and $\mathbf{2 6}$ respectively. In both cases each was shown to efficiently couple to models of their complementary partners anticipated for in vivo studies. As part of the study a protocol to avoid radiolytically triggered oxidation of $\left[{ }^{18} \mathrm{~F}\right] \mathbf{2 7}$ was developed. This adds to the repertoire of conjugates for use in fluorinase catalysed radio-synthesis for PET and shows that the fluorinase will accept a wide range of CIDA substrates tethered at C-2 of the adenine ring with a pegylated cargo.

\section{Experimental Section}

\section{Cold Transhalogenation assay}

A typical cold transhalogenation assay is exampled in 26. In a total reaction volume of $1000 \mu \mathrm{L}$ (in 50 $\mathrm{mM}$ phosphate buffer, at $\mathrm{pH} 7.8)$, recombinant fluorinase $\left(0.8 \mathrm{mg} / \mathrm{mL}^{-1}\right)$ was incubated with CIDAPEG-biotin $26(0.1 \mathrm{mM})$, L-Se-Met $(0.075 \mathrm{mM})$ and $\mathrm{KF}(50 \mathrm{mM})$ at $37^{\circ} \mathrm{C}$. Samples $(50 \mu \mathrm{L})$ were periodically removed, the protein precipitated by heating at $95{ }^{\circ} \mathrm{C}$ for $5 \mathrm{~min}$, before being clarified by centrifugation (13000 rpm, $10 \mathrm{~min}$ ). Samples of the supernatant $(40 \mu \mathrm{L})$ were removed for analysis by HPLC. HPLC analysis was performed on a Shimadzu Prominence system using a Kinetix $5 \mu \mathrm{m}$ XB-C18 
100A (150 mm $\times 4.6 \mathrm{~mm}$ ) column and a guard cartridge. Mobile phase: 0.05\% TFA in water (solvent A) and $0.05 \%$ TFA in MeCN (solvent B); Linear Gradient: $15 \%$ solvent B to $95 \%$ solvent B over $25 \mathrm{~min}, 95 \%$ for $5 \mathrm{~min}$, and back to $15 \% \mathrm{~B}$ for $10 \mathrm{~min}$ to re-equilibrate the column. Flow rate: $1 \mathrm{~mL} / \mathrm{min}^{-1}$; Detection: $254 \mathrm{~nm}$; Injection volume: $40 \mu \mathrm{L}$.

\section{HABA Assay}

Preliminary experiments were performed varying the concentrations of HABA and avidin to determine the optimal conditions for the competitive binding studies. In the final experiments a range of concentrations (0-200 $\mu \mathrm{M}$ ) of FDA-PEG-Biotin 27 and (+)-biotin were added to a HABA/avidin complex, obtained by mixing avidin and HABA to final concentrations of $(2.5 \mathrm{mg} / \mathrm{ml})$ and $0.25 \mu \mathrm{M}$ respectively. Changes in absorbance were measure at $500 \mathrm{~nm}$ and the \% inhibition was calculated using the following formula: \{[(absorbance with competitor) - (absorbance without $\mathrm{HABA}) /(\mathrm{Av}$ complex)]/[(absorbance without competitor) - (absorbance without HABA)/(Av complex)]\} $\times 100$.

\section{$\left[{ }^{18} \mathrm{~F}\right]$ Labelling of 26 to $\left[{ }^{18} \mathrm{~F}\right] 27$}

A typical ${ }^{18} \mathrm{~F}^{-}$labelling experiment of $\mathbf{2 6}$ was performed as follows: L-selenomethionine ( $40 \mu \mathrm{L}$ of a $2 \mathrm{mM}$ solution in water) and compound 26 (0.4 mg in $50 \mu \mathrm{L}$ of water) were added successively to an Eppendorf tube containing a solution of fluorinase ( $5 \mathrm{mg}$ in $50 \mathrm{~mm}$ phosphate buffer, $110 \mu \mathrm{L}$ ). The contents were mixed well with a pipette and to this mixture was added $\left[{ }^{18} \mathrm{~F}-\right.$ fluoride in $\left[{ }^{18} \mathrm{O}\right]$ water $(457 \mathrm{MBq}, 50 \mu \mathrm{L})$, making a total volume of $250 \mu \mathrm{L}$. The contents were again well mixed and incubated at $37^{\circ} \mathrm{C}$ for $30 \mathrm{~min}$. After this time the reaction was stopped and the mixture denatured by heating at $95{ }^{\circ} \mathrm{C}$ for $5 \mathrm{~min}$ and water $(400 \mu \mathrm{L}$ ) added before being clarified by centrifugation (13 $000 \mathrm{rpm}$, corresponding to $16060 \mathrm{~g}, 5 \mathrm{~min}$ ). The supernatant was injected into a Shimadzu Prominence HPLC system equipped with a quaternary pump, a degasser, a flow cell detector and a diode array detector using a Phenomenex Kingsorb C18 $(250 \times 10.00 \mathrm{~mm}, 5 \mu \mathrm{m})$ column and a guard cartridge. Mobile phase: $0.05 \%$ TFA in water (solvent A) and $0.05 \%$ TFA in MeCN (solvent B); Linear Gradient: $15 \%$ solvent B to $38 \%$ solvent B over $16 \mathrm{~min}, 95 \%$ for $5 \mathrm{~min}$, and back to $15 \%$ B for $10 \mathrm{~min}$ to re-equilibrate the column. Flow rate: $5 \mathrm{~mL} / \mathrm{min}^{-1}$. The radioactive fraction corresponding to the reference of $\left[{ }^{18} \mathrm{~F}\right] \mathbf{2 7}$ was collected, diluted with $10 \mathrm{mg} / \mathrm{mL}$ ascorbate in water $(50 \mathrm{~mL})$ and loaded onto a preactivated Waters Oasis HLB ${ }^{\circledast}$ Cartridge (conditioned with $2 \mathrm{~mL}$ EtOH and $5 \mathrm{~mL} 10 \mathrm{mg} / \mathrm{mL}$ ascorbate/water). The cartridge was washed with $20 \mathrm{~mL}$ of $10 \mathrm{mg} / \mathrm{mL}$ ascorbate/water and the desired product was collected by eluting with $0.6 \mathrm{~mL}$ of ethanol, to give $59.7 \mathrm{MBq}$ ( $13 \%$, decay uncorrected) of $>99 \%$ pure product of $\left[{ }^{18} \mathrm{~F}\right] 27$.

\section{Streptavidin binding Radio TLC assay}

To PBS buffer $(300 \mu \mathrm{L}, \mathrm{pH} 7.8)$ or streptavidin $(0.6 \mathrm{mg})$ in PBS buffer $(300 \mu \mathrm{L}, \mathrm{pH} 7.8)$ was added $\left[{ }^{18} \mathrm{~F}\right] \mathbf{2 7}$ $(0.8 \mathrm{MBq}$, in a $50 \mu \mathrm{L}$ solution of 1:5 EtOH:water), the reaction mixture was mixed well and incubated at $37^{\circ} \mathrm{C}$ for $30 \mathrm{~min}$. Thin layer chromatography was then conducted on both samples (+/- streptavidin) using aluminium plates coated with silica gel $\left(60 F_{245}\right.$ Merck), eluted with a solution 75:25:5 
MeCN:MeOH:Water. TLC plates were examined using a radio-TLC scanner to determine the percentage of streptavidin bound $\left[{ }^{18} \mathrm{~F}\right] \mathbf{2 7}$. Thin layer chromatograms radio-traces of the samples $\left[{ }^{18} \mathrm{~F}\right] 27$ in PBS buffer revealed an R/F value of 0.39 , upon incubation with streptavidin thin layer chromatograms radio-traces indicated almost completely retention of $\left[{ }^{18} \mathrm{~F}\right] \mathbf{2 7}$ (about $96 \%$ ) in the origin of the TLC plate (R/F value of 0.02 , see Supporting Information for full experimental details and Figures).

See Supporting Information for experimental detail on: Compound synthesis and characterisation, assay conditions and fluorinase overexpression and purification.

\section{Acknowledgements}

We thank the Engineering and Physical Sciences Research Council, UK, for a research grant.

Keywords: fluorinase $\cdot$ amide bioconjugation $\cdot$ tetrazine $\cdot$ biotin $\cdot{ }^{18} \mathrm{~F}$ labelling

\section{References}

[1] O. Mawlawi, D. W. Townsend, Eur. J. Nucl. Med. Mol. Imaging, 2009, 36 Suppl 1, S15-29.

[2] a) J. Hoppin, K. D. Orcutt, J. Y. Hesterman, M. D. Silva, D. Cheng, C. Lackas, M. Rusckowski, J. Pharmacol. Exp. Ther., 2011, 337, 350-358; b) M. Rashidian, E. J. Keliher, M. Dougan, P. K. Juras, M. Cavallari, G. R. Wojtkiewicz, J. T. Jacobsen, J. G. Edens, J. M. J. Tas, G. Victora, R. Weissleder, H. Ploegh, ACS Cent. Sci., 2015, 1, 142-147; c) R. Tavare, M. N. McCracken, K. A. Zettlitz, S. M. Knowles, F. B. Salazar, T. Olafsen, O. N. Witte, A. M. Wu, Proc. Natl. Acad. Sci. U. S. A., 2014, 111, 1108-1113; d) J. Clark, D. O'Hagan, J. Fluorine Chem., 2017.

[3] E. M. Sletten, C. R. Bertozzi, Angew. Chem., Int. Ed., 2009, 48, 6974-6998.

[4] a) M. Patra, K. Zarschler, H.-J. Pietzsch, H. Stephan, G. Gasser, Chem. Soc. Rev., 2016, 45, 6415-6431; b) R. Rossin, M. S. Robillard, Curr. Opin. Chem. Biol., 2014, 21, 161-169; c) J. P. Meyer, J. L. Houghton, P. Kozlowski, D. Abdel-Atti, T. Reiner, N. V. Pillarsetty, W. W. Scholz, B. M. Zeglis, J. S. Lewis, Bioconjugate Chem., 2016, 27, 298-301; d) M. L. Blackman, M. Royzen, J. M. Fox, J. Am. Chem. Soc., 2008, 130, 13518-13519; e) N. K. Devaraj, R. Weissleder, S. A. Hilderbrand, Bioconjugate Chem., 2008, 19, 2297-2299.

[5] a) J. Seckute, N. K. Devaraj, Curr. Opin. Chem. Biol., 2013, 17, 761-767; b) Z. Li, H. Cai, M. Hassink, M. L. Blackman, R. C. Brown, P. S. Conti, J. M. Fox, Chem. Commun., (Cambridge, U.K) 2010, 46, 8043-8045; c) J. C. Knight, S. Richter, M. Wuest, J. D. Way, F. Wuest, Org. Biomol. Chem., 2013, 11, 3817-3825.

[6] C. Denk, D. Svatunek, T. Filip, T. Wanek, D. Lumpi, J. Frohlich, C. Kuntner, H. Mikula, Angew. Chem., Int. Ed. Engl., 2014, 53, 9655-9659.

[7] a) E. Blom, B. Langstrom, I. Velikyan, Bioconjugate Chem., 2009, 20, 1146-1151; b) R. W. Sirianni, M. Q. Zheng, T. R. Patel, T. Shafbauer, J. Zhou, W. M. Saltzman, R. E. Carson, Y. Huang, Bioconjugate Chem., 2014, 25, 2157-2165; c) M. Mamede, T. Saga, H. Kobayashi, T. 
Ishimori, T. Higashi, N. Sato, M. W. Brechbiel, J. Konishi, Clin. Cancer Res., 2003, 9, 37563762.

[8] D. J. Hnatowich, F. Virzi, M. Rusckowski, . Nucl. Med., Society of Nuclear Medicine, 1987, 28, 1294-1302.

[9] D. M. Goldenberg, R. M. Sharkey, G. Paganelli, J. Barbet, J.-F. Chatal, J. Clin. Oncol., 2006, 24, 823-834.

[10] a) G. J. Förster, E. B. Santos, P. M. Smith-Jones, P. Zanzonico, S. M. Larson, J. Nucl. Med., 2006, 47, 140-149; bT. Kudo, M. Ueda, H. Konishi, H. Kawashima, Y. Kuge, T. Mukai, A. Miyano, S. Tanaka, S. Kizaka-Kondoh, M. Hiraoka, H. Saji, Mol. Imaging Biol., 2011, 13, 10031010.

[11] M. Simpson, L. Trembleau, R. W. Cheyne, T. A. D. Smith, Appl. Radiat. Isot., 2011, 69, 418422.

[12] a) E. Blom, O. Itsenko, B. Långström, J. Labelled Compd. Radiopharm., 2011, 54, 681-683; b) M. Claesener, H.-J. Breyholz, S. Hermann, A. Faust, S. Wagner, O. Schober, M. Schäfers, K. Kopka, Nucl. Med. Biol., 2012, 39, 1189-1194.

[13] a) T. A. D. Smith, M. Simpson, R. Cheyne, L. Trembleau, Appl. Radiat. Isot., 2011, 69, 13951400; b) L. Trembleau, M. Simpson, R. W. Cheyne, I. Escofet, M. V. C. A. L. Appleyard, K. Murray, S. Sharp, A. M. Thompson, T. A. D. Smith, New J. Chem., 2011, 35, 2496-2502.

[14] S. Thompson, Q. Zhang, M. Onega, S. McMahon, I. Fleming, S. Ashworth, J. H. Naismith, J. Passchier, D. O'Hagan, Angew. Chem., Int. Ed. Engl., 2014, 53, 8913-8918.

[15] Q. Zhang, S. Dall'Angelo, I. N. Fleming, L. F. Schweiger, M. Zanda, D. O'Hagan, Chem. Eur. J., 2016, 22, 10998-11004.

[16] D. O'Hagan, C. Schaffrath, S. L. Cobb, J. T. G. Hamilton, C. D. Murphy, Nature, 2002, 416, 279279.

[17] H. Deng, S. L. Cobb, A. R. McEwan, R. P. McGlinchey, J. H. Naismith, D. O'Hagan, D. A. Robinson, J. B. Spencer, Angew. Chem., Int. Ed. Engl., 2006, 45, 759-762.

[18] a) S. Thompson, M. Onega, S. Ashworth, I. N. Fleming, J. Passchier, D. O'Hagan, Chem. Commun., 2015, 51, 13542-13545; b) S. Thompson, I. N. Fleming, D. O'Hagan, Org. Biomol. Chem., 2016, 14, 3120-3129.

[19] a) W. L. Yeo, X. Chew, D. J. Smith, K. P. Chan, H. Sun, H. Zhao, Y. H. Lim, E. L. Ang, Ang, Chem. Commun., 2017, 53, 2559-2562; b) H. Sun, W. L. Yeo, Y. H. Lim, X. Chew, D. J. Smith, B. Xue, K. P. Chan, R. C. Robinson, E. G. Robins, H. Zhao, E. L. Ang, Angew. Chem., Int. Ed. Engl., 2016, 55, 14277-14280.

[20] P. T. Lowe, S. Dall'Angelo, T. Mulder-Krieger, A. P. ljzerman, M. Zanda, D. O'Hagan, Chembiochem., 2017, 18, 2156-2164.

[21] M. Asti, M. Iori, P. A. Erba, G. Atti, D. Farioli, C. Guidotti, A. Versari, Nucl. Med. Commun., 2012, 33, 1179-1187.

[22] a) A. Bogusiewicz, S. L. Stratton, D. A. Ellison, D. M. Mock, Am. J. Clin. Nutrit., 2008, 88, 12911296; b) K. S. Wang, A. Patel, D. M. Mock, J. Nutr., 1996, 126, 1852-1857; c) J. Zempleni, D. B. McCormick, D. M. Mock, Am. J. Clin. Nutr., 1997, 65, 508-511.

[23] D. M. Mock, G. L. Lankford, N. I. Mock, J. Nutr., 1995, 125, 941-946.

[24] a) P. J. Scott, B. G. Hockley, H. F. Kung, R. Manchanda, W. Zhang, M. R. Kilbourn, Appl. Radiat. Isot., 2009, 67, 88-94; bR. M. Fawdry, Appl. Radiat. Isot.,2007, 65, 1193-1201. 


\section{Entry for the Table of Contents}

\section{FULL PAPER}

The synthesis and evaluation of new amine and acid functionalized fluorinase substrates, allowing for the attachment to an extensive range of carboxylate or amine containing bioactive molecules to a fluorinase binding 5'-CIDA moiety, prior to their enzymatic radiolabelling with $\left[{ }^{18} \mathrm{~F}\right]$ fluoride. Two new substrates of this class have been designed specifically for their application towards a pretargeting approach for radiolabelling conjugated antibodies and proteins for PET imaging.

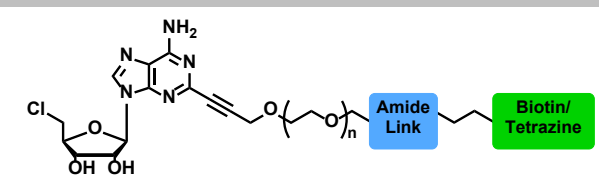

Phillip T. Lowe, ${ }^{[a]}$ Sergio Dall'Angelo, ${ }^{[b]}$ Andrew Devine, ${ }^{[a]}$ Matteo Zanda, ${ }^{[b]}$ and David O'Hagan*[a]

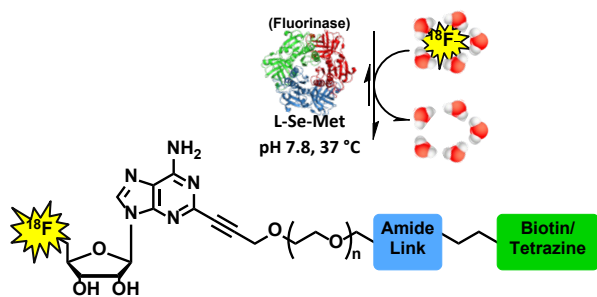

Page No. - Page No.

Enzymatic fluorination of biotin and tetrazine conjugates for pre-targeting approaches to PET imaging. 